\title{
Burnout in Physicians and Nurses Working in Obstetrics/Gynecology Clinics in Turkey
}

\author{
Türkiye'de Obstetri ve Jinekoloji Kliniklerinde \\ Çalışan Doktorlar ve Hemşirelerde Tükenmişlik
}

\section{Hüsnü Töre YAVUZŞEN, ${ }^{a}$ Özgül VUPA ÇILENGIROĞLUb}

${ }^{a}$ Clinic of Gynecology and Obstetrics, Buca Obstetrics Gynecology and Pediatrics Disease Hospital, bepartment of Statistics, Dokuz Eylul University Faculty of Sciences, İzmir

Geliş Tarihi/Received: 29.01 .2015 Kabul Tarihi/Accepted: 05.06.2015

Yazışma Adresi/Correspondence: Hüsnü Töre YAVUZŞEN Buca Obstetrics Gynecology and Pediatrics Disease Hospital, Clinic of Gynecology and Obstetrics, İzmir, TÜRKIYE/TURKEY drtoreyavuzsen@yahoo.com

\begin{abstract}
Objective: To evaluate the burnout and to determine the relationship demographic characteristics and burnout levels between physicians and nurses working in 3 different obstetrics/gynecology clinics. Material and Methods: This is an observational cross-sectional study and included in 47 physicians and 90 nurses. We used to quantitative survey to assess burnout levels using a Turkish version of the Maslach Burnout Inventory. Results: Results showed that the women perceived lower personal sense of accomplishment compared to the men for physicians $(\mathrm{p}=0.013)$, and the single demonstrated lower personal sense of accomplishment compared to the married physicians $(\mathrm{p}=0.003)$. Two government hospitals created differences according to emotional exhaustion and depersonalization levels $(\mathrm{p}=0.046, \mathrm{p}=0.034)$. The mean age of physicians was higher than that of nurses $(\mathrm{p}=0.036)$. The working hour per-day for nurses was higher than physicians $(\mathrm{p}=0.000)$. Physicians showed higher levels of burnout in emotional exhaustion, depersonalization, and lower level of personal sense of accomplishment subscales compared to the nurses. However there was a statistical difference between nurses and physicians for depersonalization and personal sense of accomplishment subscales ( $\mathrm{p}=0.000, \mathrm{p}=0.013$ ). Correlation analyses in physicians showed that age was significantly negatively correlated with depersonalization $(\mathrm{p}=0.006)$. Increasing age among nurses was found when the level of depersonalization subscale is decreasing like physicians $(\mathrm{p}=0.012)$. Conclusion: The levels of burnout have been shown high in the obstetric gynecology physicians. The burnout syndrome was observed more in female gender, single ones, and younger age both of healthcare workers. Further researches should be evaluated the interrelationships among the burnout, job career satisfaction, and psychosocial health in the obstetric gynecologic physicians.
\end{abstract}

Key Words: Burnout, professional; medical staff, hospital; nurses

ÖZET Amaç: Üç ayrı obstetrik/jinekoloji kliniğinde çalışan hemşire ve doktorlar arasında tükenmişlik seviyeleri ve demografik özellikler arasındaki ilişkileri değerlendirmektir. Gereç ve Yöntemler: Kırk yedi doktor ve 90 hemşirenin dâhil edildiği kesitsel gözlemsel bir çalışmadır. Türkçe versiyonu olan Maslach Tükenmişlik Envanteri kullanılarak tükenmişlik seviyeleri kantitatif olarak ölçülmüştür. Bulgular: Kadın cinsiyet ve bekâr olma, evli ve erkek cinsiyet ile karşılaştırıldığında daha düşük kişisel başarı skorlarının elde edildiğini sonuçlar da göstermiștir $(\mathrm{p}=0,013, \mathrm{p}=0,003)$. İki kamu hastaneleri arasında emosyonel tükenmişlik ve depersonalizasyon puanları açısından fark saptandığı gösterilmiştir ( $\mathrm{p}=0,046$, $\mathrm{p}=0,034)$. Doktorların ortalama yașı hemșirelere göre daha ileriydi $(\mathrm{p}=0,036)$. Günlük çalıșma saatleri açısından ise hemşireler daha yoğun çalışmaktaydı $(\mathrm{p}=0,000)$. Doktorlarda daha yüksek emosyonel tükenmişlik ve depersonalizasyon, daha düșük kișisel bașarı alt skorları olmak üzere tükenmişlik sendromu hemşirelere göre fazlayd. Bununla beraber hemşireler ve doktorlar arasında depersonalizasyon ve kișisel bașarı puanları açısından istatistiksel anlamlı fark saptandı $(\mathrm{p}=0,000, \mathrm{p}=0,013)$. Korelasyon analizleri uygulandı̆̆ında doktorlarda yaş ile depersonalizasyon arasında negatif bir ilişki bulundu ( $\mathrm{p}=0,006)$. Hemşireler arasında da yaş artıkça depersonalizasyon puanları doktorlarda olduğu gibi azalmaktaydı $(\mathrm{p}=0,012)$. Sonuç: Obstetri ve jinekoloji doktorlarında tükenmişlik seviyeleri yüksek olduğu gösterilmiştir. Kadın cinsiyet, bekârlarda ve genç yaşlarda tükenmişlik sendromunun daha fazla olduğu her iki sağlık çalışan grubunda gözlendi. İleriki araştırmalar obstetri/jinekoloji doktorlarında tükenmişlik sendromu ile iş kariyer tatmini ve psikososyal sağlık ilişkisini değerlendirmek olmalıdır.

Anahtar Kelimeler: Tükenmişlik, mesleki; sağlık çalışanları, hastane; hemşireler

Turkiye Klinikleri J Gynecol Obst 2015;25(3):160-7 


\section{B} urnout is an increasing problem among the health care workers and is common in the care settings. It is a syndrome that describes as the state of tiredness, disappointment, and hopelessness in workers. ${ }^{1}$ It was characterized by low personal sense of accomplishment (PA), emotional exhaustion (EE), and depersonalization in relationship (D) according to Maslach and Goldberg., ${ }^{2,3}$ Health care workers had often faced with the burnout syndrome due to working conditions and other factors. ${ }^{4,5}$ Syndrome is associated with impaired performance, decreased mental and physical health. In this case, individual feels him or herself as exhausted and stressed too much in professional life, decreased job performance and commitment, predicts stress-related health problems, and low career satisfaction.

Health care workers in obstetrics and gynecology clinics often require enough energy to confront all problems and self-devotion. Little is known about the prevalence of burnout in obstetrician and gynecologists [ob/gyns] and also nurses working in obstetrics and gynecology clinics. Gabbe et al. published in study that burnout in chairs of obstetrics and gynecology. ${ }^{6}$ It was found that burnout and high EE were more common in new chairs, those who had served less than 5 years, who worked nearly 70 hours each week, and who had less spouse/partner support. Emotional exhaustion is the main subscale for burnout syndrome. Conflicts over fast treatment decisions can cause to the stress factors and emotional exhaustion for ob/gyns. ${ }^{7}$ Burnout syndrome is also prevalent among other specialists. ${ }^{7-13}$ According to these studies health workers may experience multiple stressors including a sense of failure or frustration when patient's illness progresses, feelings of powerlessness against illness and its associated losses, role conflicts and ambiguity, and the failure to enable a good death.

The Maslach Burnout Inventory [MBI], the most widely used standardized measure of burnout, was the basis of determining the prevalence of burnout in the study sample. It was translated into Turkish language and its' reliability was recalculated by Ergin. ${ }^{14,15}$ Questionnaire comprising of 22 questions is considered as the gold standard measuring tool for burnout. In Turkey, health care workers including physicians and nurses have many factors inducing burnout such as environment and job related factors. ${ }^{1,4,5,7}$ Many publications have been made in this field in Turkey. ${ }^{16-23}$ However, the number of studies conducted by physicians and nurses working in obstetric and gynecology clinics are very few. ${ }^{13,24}$ With this study, we aimed to measure the burnout levels and to determine the relation between the health care professionals working in different obstetrics and gynecology clinics in Turkey.

\section{MATERIAL AND METHODS}

An observational cross-sectional study was consisted a sample group of 47 physicians and 90 nurses working in 3 different obstetrics and gynecology clinics in Izmir. Participants were included between the March and April 2012. We used to quantitative survey to assess burnout levels in participants as well as sociodemographic variables, and used the statistical methods to investigate the relationship between demographic characteristics and burnout levels in physicians and nurses. This study has been approved from Ethics Committee in Dokuz Eylul University Faculty of Medicine. All data were analyzed in compliance with the Helsinki Declaration. Every participant of the study gave verbal consent.

Data were collected using a series of forms completed during face-to-face interviews by trained interviewers. The first form consisted of questions regarding the demographic characteristics and working conditions of the physicians and nurses. The first section included the name of obstetrics and gynecology clinics, gender, age, marital status, working place of nurses and working hour per day. The second form was the Turkish version of the MBI. MBI has three subscales. Emotional exhaustion (EE) consists of 9 items measuring the reduced energy, emotional, and cognitive distancing from the job; the depersonalization (D) of 5 items measuring cynicism, lack of engagement, and distancing from the patients, treatment of patients as inanimate, unfeeling objects, and the per- 
sonal sense of accomplishment (PA) of 8 items measuring perception of having an influence on others, working well with others and dealing well with problems. ${ }^{10}$ Each item had a 5-point rating scale $(0=$ never, $1=\mathrm{a}$ few times a year; $2=\mathrm{a}$ few times a month; $3=$ a few times a week; $4=$ every day). High scores on the EE or D subscales were indicative of burnout, as do low scores on the PA subscale. ${ }^{5} \mathrm{~A}$ high level of burnout was defined as a high level of EE (score of 27 or higher), a high level of D (score of 10 or higher), and a low level of PA (score of 33 or lower) based on normative data from a sample of American health professionals. ${ }^{10,16} \mathrm{We}$ used these cut-off scores to determine the levels of burnout. Reliability analysis of the MBI in our study group indicated that it was a reliable instrument with high coefficients of internal consistency (Cronbach's $\alpha=0.90$ for $E E, \alpha=0.77$ for $D$, and $\alpha=0.74$ for PA subscales).

Collected data was analyzed using SPSS statistical software package (v.11.5; Chicago, USA). A reliability analysis was carried out and Cronbach's alpha levels were obtained for internal consistency of the measurement scales. The descriptive statistics were obtained from the demographic characteristics and working conditions of the physicians and nurses and MBI subscales for physicians and nurses. These statistics were summarized by frequencies and percentages for categorical, and means and standard deviations (SD) for continuous variables. We used the independent two sample $t$ test to find the whether the significance difference between physicians and nurses for the levels of burnout subscales is or not. Pearson and Spearman correlation analysis were used to evaluate the relationship and relationship level between MBI subscales and the demographic characteristics. We used the independent two sample $t$ test and oneway analysis of variance to find the whether the significance difference among MBI subscales between physicians and nurses according to demographic characteristics.

\section{RESULTS}

Hundred thirty seven health care workers who are working in 3 different obstetrics and gynecology clinics in Izmir were surveyed and included in this study. A questionnaire form was performed to 47 physicians and 90 nurses. A reliability analysis was carried out for the study items of this questionnaire form. After finding reliabilities of these MBI subscales, descriptive statistics were obtained from MBI subscales. Minimum scores were found to be 13, 16 and 5 for EE, PA and D subscales, respec-

TABLE 1: Frequency distribution of demographic variables of the physicians and their burnout levels in three subscales.

\begin{tabular}{|c|c|c|c|c|}
\hline Variables & $\mathrm{N}(\%)$ & $\mathrm{EE}($ mean $\pm \mathrm{SD})$ & $\mathrm{D}(\mathrm{mean} \pm \mathrm{SD})$ & $\mathrm{PA}($ mean $\pm \mathrm{SD})$ \\
\hline \multicolumn{5}{|l|}{ Clinics } \\
\hline Buca & $13(27.7)$ & $33.38 \pm 4.05$ & $11.15 \pm 2.58$ & $28.77 \pm 3.52$ \\
\hline Konak & $11(23.4)$ & $30.36 \pm 6.12$ & $11.73 \pm 3.32$ & $29.00 \pm 2.97$ \\
\hline Tepecik & $23(48.9)$ & $28.00 \pm 6.89$ & $14.04 \pm 3.75$ & $27.39 \pm 4.21$ \\
\hline $\mathrm{p}$-value (F test) & & $0.046^{*}$ & $0.034^{*}$ & 0.407 \\
\hline p-value (Tukey test) & & $0.036^{*}$ & $0.045^{\star}$ & \\
\hline \multicolumn{5}{|l|}{ Marital Status } \\
\hline Married & $42(89.4)$ & $30.02 \pm 6.33$ & $12.41 \pm 3.48$ & $28.69 \pm 3.45$ \\
\hline Single & $5(10.6)$ & $30.20 \pm 7.32$ & $15.20 \pm 3.56$ & $23.60 \pm 3.51$ \\
\hline P-value (t test) & & 0.954 & 0.097 & $0.003^{*}$ \\
\hline \multicolumn{5}{|l|}{ Gender } \\
\hline Male & $29(61.7)$ & $29.10 \pm 6.49$ & $13.17 \pm 3.79$ & $29.21 \pm 3.52$ \\
\hline Female & 18 (38.3) & $31.56 \pm 5.99$ & $11.94 \pm 3.09$ & $26.44 \pm 3.62$ \\
\hline $\mathrm{p}$-value (t test) & & 0.202 & 0.254 & $0.013^{*}$ \\
\hline
\end{tabular}

${ }^{*}$ Significant $(p<0.05)$.

SD: Standart deviation. 
TABLE 2: Frequency distribution of demographic variables of the nurses and their burnout levels in three subscales.

\begin{tabular}{|lcccc|}
\hline Variables & N (\%) & EE (mean \pm SD) & D (mean \pm SD) & PA (mean $\pm S D)$ \\
Clinics & & & & $28.19 \pm 6.58$ \\
Buca & $41(45.6)$ & $28.19 \pm 6.58$ & $9.51 \pm 3.34$ & $27.58 \pm 6.97$ \\
Konak & $26(28.9)$ & $27.58 \pm 6.97$ & $10.13 \pm 3.69$ & $26.52 \pm 8.82$ \\
Tepecik & $23(25.6)$ & $26.52 \pm 8.33$ & 0.682 & \\
p-value (F test) & 0.682 & 0.278 & & $30.27 \pm 4.38$ \\
Marital Status & & & $9.79 \pm 3.25$ & $29.26 \pm 4.57$ \\
Married & $71(78.9)$ & $27.21 \pm 7.11$ & $10.79 \pm 4.67$ & 0.381 \\
Single & $19(21.2)$ & $29.00 \pm 7.89$ & & \\
p-value (t test) & 0.344 & 0.283 & $9.47 \pm 3.68$ & $30.07 \pm 4.59$ \\
Working Place & & & $10.06 \pm 3.81$ & $30.41 \pm 4.40$ \\
Emergency & 15 & $28.13 \pm 8.02$ & $10.23 \pm 3.05$ & $29.18 \pm 4.39$ \\
Service & 53 & $27.30 \pm 7.71$ & 0.550 & \\
Obstetrics & 22 & $27.01 \pm 5.78$ & 0.809 & \\
p-value (t test) & 0.903 & & & \\
\hline
\end{tabular}

${ }^{*}$ Significant $(p<0.05)$.

SD: Standart deviation.

tively. Maximum scores were also found to be 45, 39 and 23 for EE, PA and D subscales, respectively. Means of scores $(\mathrm{x} \pm \mathrm{SD})$ were found to be (28.43 \pm 7.04$),(29.40 \pm 4.29)$ and $(10.93 \pm 3.79)$ for EE, PA and D subscales, respectively.

The frequency distribution of the physicians and nurses according to demographic variables and the level of burnout were summarized in Table 1 and 2. This study was consisted a sample group of 47 (34.3\%) physicians and 90 (65.7\%) nurses. The majority of physicians were male (61.7\%), whereas all nurses were female. Most of the physicians and nurses were both married. Our results showed that the women perceived lower PA ( $\mathrm{p}=0.013)$ compared to the men for physicians and, the single physicians demonstrated lower PA ( $\mathrm{p}=0.003)$ compared to the married physicians. Mean EE and D levels of physicians were found different among clinics ( $\mathrm{p}=0.046$ for $\mathrm{EE}, \mathrm{p}=0.034$ for $\mathrm{D}$ ). Mean EE level of physicians who work in Buca was found significantly higher than that of physicians who work in Tepecik according to Tukey test $(\mathrm{p}=0.036)$. Mean D level of physicians who work in Buca was found significantly lower than that of physicians who work in Tepecik according to Tukey test $(\mathrm{p}=0.045)$. It meant that Buca and Tepecik hospitals created differences according to EE and $\mathrm{D}$ lev-

\begin{tabular}{|lccr|}
\hline TABLE 3: & $\begin{array}{c}\text { Demographic variables [continuous] of the } \\
\text { physicians and nurses. }\end{array}$ & \\
\hline Variables & & & p-value \\
(mean \pm std) & Physicians & Nurses & (t-test) \\
Age (year) & $38.34 \pm 8.09$ & $35.49 \pm 7.12$ & $0.036^{*}$ \\
Working hour per day & $8.42 \pm 0.68$ & $12.76 \pm 6.80$ & $0.000^{*}$ \\
\hline
\end{tabular}

* Significant $[p<0.05]$.

$\mathrm{SD}$ : Standart deviation.

els. "Clinics", "marital status" and "working place" variables of nurses were not found statistically different for all these subscales.

"Age" and "working hour per day" variables were continuous. For this reason, means of these variables of physicians and nurses were compared by independent two samples test for physician and nurse group in Table 3. The mean age of physicians was higher than that of nurses (38.34 vs. $35.49, \mathrm{p}=0.036$ ). On the other hand, the working hour per day for nurses was higher than physicians ( 12.76 vs. $8.42, \mathrm{p}=0.000$ ). In other words, there was statistically difference between two groups for these two variables.

Cut-off levels of burnout were defined as a high level of EE and D, and a low level of PA based on normative data from a sample of physicians and 
nurses. Seventy-two percent of the physicians and $52 \%$ of the nurses had high EE and, $77 \%$ of the physicians and $50 \%$ of the nurses had high $\mathrm{D}$ and, $94 \%$ of the physicians and $78 \%$ of the nurses had low PA levels.

The independent two sample t test was used to find the whether the significance difference between physicians and nurses for the levels of burnout subscales is or not. Physicians showed higher levels of burnout in EE and D subscales compared to the nurses in Table 4, but no significance difference was found between two groups regarding EE subscale $(\mathrm{p}=0.053)$. However, there was statistically significant difference between two groups in the level of $\alpha=0.10$. On the other hand, there was a statistical difference between two groups for $\mathrm{D}$ subscale $(\mathrm{p}=0.000)$. Nurses showed higher levels of burnout in PA subscale compared to the physicians and the significance difference was found between two groups.

Significant correlations were found in MBI subscales for physicians and nurses. Correlation analyses for physicians and nurses were given in Table 5. Correlation analyses in physicians showed that age was significantly negatively correlated with D subscale $(r=-0.397)$. Decreasing age among physicians was found when the level of $D$ subscale is increasing. On the other hand, D subscale was significantly positively correlated with EE subscale ( $r=0.374)$. Correlation analyses in nurses showed that PA subscale was significantly negatively correlated with $\mathrm{EE}$ and D subscales, respectively ( $r=-0,387$ and $r=-0,339)$. Increasing age among nurses was found when the level of $\mathrm{D}$ subscale is decreasing $(\mathrm{r}=-0.263)$.

\section{DISCUSSION}

The health care workers including physicians and nurses have many factors inducing burnout such as psychosocial, job-related, family, and environmental factors. The burnout prevalence is from $25 \%$ to $60 \%$ among with practicing physicians from all specialties. ${ }^{25}$ In this study, we have described the job profile according to hospitals of working health care workers with obstetrician and gynecology clinics in Turkey.

\begin{tabular}{|c|c|c|c|}
\hline MBI & & & $\mathrm{p}$-value \\
\hline subscales & Physicians & Nurses & [t-test] \\
\hline $\mathrm{EE}$ & $30.04 \pm 6.35$ & $27.59 \pm 7.27$ & 0.053 \\
\hline D & $12.70 \pm 3.56$ & $10.00 \pm 3.59$ & $0.000^{*}$ \\
\hline PA & $28.15 \pm 3.77$ & $30.06 \pm 4.41$ & $0.013^{*}$ \\
\hline
\end{tabular}

* Significant $[\mathrm{p}<0.05]$.

MBI: The Maslach Burnout Inventory; EE: Emotional exhaustion; D: Depersonalization in relationship; PA: Personal sense of accomplishment.

TABLE 5: Correlations between age and MBI subscales in two groups.

\begin{tabular}{|c|c|c|c|}
\hline Group & $\begin{array}{l}\mathrm{MBI} \text { and } \\
\text { variables }\end{array}$ & $\begin{array}{l}\text { Correlation } \\
\text { coefficient }[r]\end{array}$ & $\begin{array}{l}\text { p-value } \\
\text { [t-test] }\end{array}$ \\
\hline \multirow[t]{2}{*}{ Physicians } & $\mathrm{EE}$ and $\mathrm{D}$ & 0.374 & 0.010 \\
\hline & $\mathrm{D}$ and age & $-0.397^{\star}$ & 0.006 \\
\hline \multirow[t]{4}{*}{ Nurses } & $\mathrm{EE}$ and $\mathrm{PA}$ & $-0.387^{\star}$ & 0.000 \\
\hline & $\mathrm{EE}$ and $\mathrm{D}$ & 0.434 & 0.000 \\
\hline & $\mathrm{D}$ and age & $-0.263^{*}$ & 0.012 \\
\hline & PA and D & -0.339 & 0.001 \\
\hline
\end{tabular}

* Pearson.

MBI: The Maslach Burnout Inventory; EE: Emotional exhaustion; D: Depersonalization in relationship; PA: Personal sense of accomplishment.

We found that prevalence of high levels of $D$, $\mathrm{EE}$, and low level of PA subscales in physicians and nurses was found higher according to existing studies. ${ }^{6,26}$ This may be related to the effects of cultural, environmental factors and working conditions or the small number of participants. The first important finding in our study, the men perceived higher PA compared to the women for physicians, and the single physicians demonstrated lower PA compared to the married ones. It was emphasized by the Maslach vulnerability of women as they display with more empathy than men. ${ }^{27}$ In literature there are many studies that support these findings. ${ }^{4-10}$ In a meta-analysis of 25 studies conducted by Schernhammer and Colditz was found that suicidal thoughts of female physicians were higher than males when compared to general population. ${ }^{28}$

Levels of other subscales, D and EE couldn't any statistically differences between marital statuses and gender in physicians. These findings were similar to previous studies..$^{29,30}$ Our results male physicians are shown higher D and lower EE subscales than their female physicians; however they 
feel more accomplished than women. This is probably explained by the cultural characteristics of the image of men in Middle East Countries.

There are many studies published evaluating the level of burnout of health care workers working in oncology and emergency department, not obstetric and gynecology department in Turkey. Our study found that mean EE and D levels of physicians who work in Buca and Tepecik Hospitals in Izmir were found statistical difference. EE level in Buca was greater than Tepecik Hospital and D level in Buca was less than Tepecik hospital in Izmir. All clinics are government hospitals but one of them (Tepecik) is Training/Research hospital, and other (Konak) is an accepting physician for the training of fellows in the form of rotation. Although the patient load and the characteristics of the hospitals are similar, the working conditions in especially in physicians might be different. This difference may be explained with these conditions. In Turkey, the work environment of physicians is very different. They contain several factors that might induce burnout. Nurse to physician ratio, work overload, direct and indirect exposure to patients who have a chronic illness, a lack of rewards, and limited professional expectations also might contribute to the increased frequency of burnout among physicians in Turkey.

In the nurses, we couldn't find any statistical significance according to clinics, marital status, and working place such as obstetrics or services nurses. Small number of nurses and different working places reveal a bias in these findings. In contrast to previous studies, physicians showed higher levels of EE, D, and lower levels of PA compared to the nurses in our study. ${ }^{29,31-33}$ Study of the Keeton and colleagues was to explore factors related with physician career satisfaction, work-life balance, and burnout in department of obstetrics and gynecology. ${ }^{34}$ They found that burnout is an important predictor of career satisfaction, control over schedule, and work hours. Our study job experience of physicians according to year might higher than nurses, and $50 \%$ of nurses were under 35 years old. Malpractice concerns and ethical problems are im- portant and may also be at risk for burnout in ob/gyns physicians working in different countries in world. Another study from Turkey was to evaluate role conflict, role ambiguity, and burnout in nurses and physicians at a university hospital. They demonstrated that role conflict and ambiguity might contribute the development of burnout and nurses and physicians who were at the beginning of their professional life experienced the highest level of EE. In our study, we did not ask the year of working, this is our lacking. Another study was very nicely undertaken with ob/gyns residents. ${ }^{35} \mathrm{It}$ was measured career satisfaction and assesses its relationship to burnout, depression, and malpractice concerns. They found that physicians' career satisfaction was inversely correlated with burnout and depression. Another important issue was emphasized by Studdert et al., physicians practicing obstetrics and gynecology, emergency medicine, general surgery, orthopedic surgery, neurosurgery, radiology, and high risk specialties are entitled to legal representation. ${ }^{36,37}$ They observed that high risk specialist physicians practiced defensive medicine. There might be strong correlation with defensive medicine and occupational group, academic tasks, work experiences, places. Defensive medicine among obstetricians and gynecologists might be effect in our study findings.

The mean age of physicians was higher than nurses and the working hour per day for nurses was higher than physicians in our study. We found significant correlations in burnout subscales at physicians and nurses. Age among physicians and nurses was found inversely correlated with D subscale. Depersonalization was positively correlated with EE. The level of burnout was significantly high in younger physicians and nurses. Only in nurses PA was found negatively correlated with D and EE. This is an expected result. We may not have found physicians due to insufficient number. The Finnish study results are inversely to ours. They found that age does not protect against burnout. ${ }^{38}$ Age might aggravate the cumulative nature of job stress in today and older age workers might run away from the patients. This may be reflection for our results. 
We evaluated large numbers of physicians and nurses working in 3 different big clinics in city of İzmir to measure burnout. Some study limitations should be considered: our study design was surveyed in cross-sectional nature, and data collection method, which create difficulties in ascertaining causality. We used self reported data collected at one point in time, and do not evaluated with psychological status such as depression and also job satisfaction. Another limitation is that age and working hour per day were different between groups and we did not correlate these parameters because of not enough participants. We all know that working year of in the same field is important concern. However we did not check for this issue, this is other limitation of our study. But most of the participant especially in nurses working year is very low.
In conclusion, ob/gyns physicians were shown higher levels of burnout compared to nurses. Subgroup analyses found that men perceived higher PA scores compared to women for physicians, and the single physicians demonstrated lower PA compared the married physicians. Women and single physicians were low PA scores. Further researches should be evaluated the interrelationships among the burnout, job career satisfaction, and psychosocial health in the ob/gyn physicians. Also researches for prevention, identification, management, and consequences of burnout should be taken into account.

\section{Acknowledgement}

The authors would like to thank all staff who gave their time to participate in the study.

\section{REFERENCES}

1. Fredeunberger HJ. The issues of staff burnout in therapeutic communities. J Psychoactive Drugs 1986;18(3):247-51.

2. Maslach C. Burned-out. Can J Psychiatr Nurs 1979;20(6):5-9.

3. Maslach C, Goldberg J. Prevention of burnout: new perspectives. Appl Prevent Psychol 1998;7(1):63-74.

4. Demir A, Ulusoy M, Ulusoy MF. Investigation of factors influencing burnout levels in the professional and private lives of nurses. Int $\mathrm{J}$ Nurs Stud 2003;40(8):807-27.

5. Ozyurt A, Hayran O, Sur H. Predictors of burnout and job satisfaction among Turkish physicians. Q J Med 2006;99(99):161-9.

6. Gabbe SG, Melville J, Mandel L, Walker E. Burnout in chair of obstetrics and gynecology: diagnosis, treatment, and prevention. Am J Obstet Gynecol 2002;186(4):601-12.

7. Yoon JD, Rasinski KA, Curlin FA. Conflict and emotional exhaustion in obstetrician-gynecologists: a national survey. $J$ Med Ethics 2010;36(12):731-5.

8. Isikhan V, Comez T, Danis MZ. Job stress and coping strategies in health care professionals working with cancer patients. Eur $\mathrm{J}$ Oncol Nurs 2004;8(3):234-44.

9. Asai M, Morita T, Akechi T, Sugawara Y, Fujimori M, Akizuki N, et al. Burnout and psychiatric morbidity among physicians engaged in end-of-life care for cancer patients: a crosssectional nationwide survey in Japan. Psychooncology 2007;16(5):421-8.
10. Whippen DA, Canellos GP. Burnout syndrome in the practice of oncology: results of a random survey of 1,000 oncologists. J Clin Oncol 1991;9(10):1916-20.

11. Marcelino G, Cerveira JM, Carvalho I, Costa JA, Lopes M, Calado NE, et al. Burnout levels among Portuguese family doctors: a nationwide survey. BMJ Open 2012;2(3).pii:e001050.

12. Piko BF. Burnout, role conflict, job satisfaction and psychosocial health among Hungarian health care staff: a questionnaire survey. Int $J$ Nurs Stud 2006;43(3):311-8.

13. Elit L, Trim K, Mand-Bains IH, Sussman J, Grunfeld E; Society of Gynecologic Oncology Canada. Job satisfaction, stress, and burnout among Canadian gynecologist oncologist. Gynecol Oncol 2004;94(1):134-9.

14. Maslach C, Jackson SE, Leiter MP. Maslach Burnout Inventory Manual. $3^{\text {rd }}$ ed. Palo Alto, CA: Consulting Psychologists Press; 1996. p.52.

15. Ergin C. Adaptation of Maslach Burnout Inventory for Turkish nurses and physicians. VII. Ulusal Psikoloji Kongresi Bilimsel Çalıșmaları. Ankara: Türk Psikologlar Derneği; 1992. p.143-55.

16. Cam 0 . The burnout in nursing academicians in Turkey. Int J Nurs Stud 2001;38(2):201-7.

17. Taycan O, Taycan SE, Celik C. Relationship of burnout with personality, alexithymia, and coping behaviors among physicians in a semiurban and rural area in Turkey. Arch Environ Occup Health 2014;69(3):159-66.
18. Sevencan F, Cayir E, Uner S. Burnout status of interns and associated factors. Cah Sociol Demogr Med 2010;50(4):501-15.

19. Tunc T, Kutanis RO. Role conflict, role ambiguity, and burnout in nurses and physicians at a university hospital in Turkey. Nurs Health Sci 2009;11(4):410-6.

20. Demirci S, Yildirim YK, Ozsaran Z, Uslu R, Yalman D, Aras AB. Evaluation of burnout syndrome in oncology employees. Med Oncol 2010;27(3):968-74.

21. Ozyurt A, Hayran M, Sur H. Predictor of burnout and job satisfaction among Turkish physicians. QJM 2006;99(3):161-9.

22. Cobanoglu N, Algier L. A qualitative analysis of ethical problems experienced by physicians and nurses in intensive care units in Turkey. Nurs Ethics 2004;11(5):444-58.

23. Cevik AA, Holliman CJ, Yanturali S. [Emergency physicians and "burn out" syndrome]. Ulus Travma Acil Cerrahi Derg 2003;9(2):85-9.

24. Lupo FN, Arnaboldi P, Santoro L, D'Anna E, Beltrami C, Mazzoleni EM, et al. The effects of a multimodal training program on burnout syndrome in gynecology oncology nurses and on the multidisciplinary psychosocial care of gynecologic cancer patients: an Italian experience. Palliat Support Care 2013;11(3):199203.

25. Shanafelt TD, Bradley KA, Wipf JE, Back AL. Burnout and self-reported patient care in an internal medicine residency program. Ann Int Med 2002;136(5):358-67. 
26. Gabbe SG, Webb LE, Moore DE Jr, Mandel LS, Melville JL, Spickard WA Jr. Can mentors prevent and reduce burnout in new chairs of departments of obstetrics and gynecology: results from a prospective, randomized pilot study. Am J Obstet Gynecol 2008;198(6): 653e1-7.

27. Maslach C, Jackson SE. The measurement of experienced burnout. J Occup Behav 1981;2(2):99-113.

28. Schernhammer ES, Colditz AG. Suicide rates among physicians: a quantitative and gender assessment (meta-analysis). Am J Psychiatry 2004;161(12): 2295-302.

29. Alacacioglu A, Yavuzsen T, Dirioz M, Oztop I, Yilmaz U. Burnout in nurses and physicians working in oncology department. Psychooncology 2009;18(5):543-8.

30. Raftopoulos V, Charalambous A, Talias M. The factors associated with the burnout syn- drome and fatigue in Cypriot nurses: a census report. BMC Public Health 2012;12:457.

31. Tunc T, Kutanis RO. Role conflict, role ambiguity, and burnout in nurses and physicias at a university hospital in Turkey. Nurs Health Sci 2009;11(4):410-6.

32. Wu SY, Li HY, Wang XR, Yang SJ, Qui H. A comparison of the effect of work stress on burnout and quality of life between female nurses and female doctors. Arch Environ Occup Health 2011;66(4):193-200.

33. Renzi C, Di Pietro C, Tabolli S. Psychiatric morbidity and emotional exhaustion among hospital physicians and nurses: association with perceived job-related factors. Arch Environ Occup Health 2012;67(2):117-23.

34. Keeton K, Fenner DE, Johnson TR, Hayward RA. Predictors of physician career satisfaction, work-life balance, and burnout. Obstet Gynecol 2007;109(4):949-55.
35. Becker JL, Milad MP, Klock SC. Burnout, depression, and career satisfaction: cross-sectional study of obstetrics and gynecology residents. Am J Obstet Gynecol 2006;195(5): 1444-9.

36. Studdert DM, Mello MM, Sage WM, DesRoches CM, Peugh J, Zapert K, et al. Defensive medicine among high-risk specialist physicians in a volatile malpractice environment. JAMA 2005;293(21):2609-17.

37. Anderson BL, Strunk AL, Schulkin J. Study on defensive medicine practices among obstetricians and gynecologists who provide breast care. J Healthc Qual 2011;33(3):3743.

38. Ahola $\mathrm{K}$, Honkonen $\mathrm{T}$, Isometsä $\mathrm{E}$, Kalimo R, Nykyri E, Koskinen S, et al. Burnout in the general population. Results from the Finnish Health 2000 Study. Soc Psychiatr Epidemiol 2006;41(1):11-7. 